\title{
Networking through online geographic learning: A Pan American experience
}

\section{Red dinámica a través del aprendizaje online. Una experiencia Panamericana}

Osvaldo Muñiz Solari*

Fecha de recibido: 05 de octubre de 2019

Fecha de aceptado: 10 de noviembre de 2019

\begin{abstract}
Online education represents a more advanced e-learning level than distance education. The former represents a networking process generated by members that integrate a community of practice. This article describes the development of an online education experience through a dynamic network of nodes represented by in-service high school geography and social science teachers. The project identified as "RedOnline-IPGH" had a Pan American dimension by its geographic extension.

A digital portal created at Texas State University, identified as Node-1, coordinated a network of 16 additional nodes localized in several countries of Central America and South America. Node-1 in North America kept a permanent connection with all the nodes to effectively conduct a synchronous and asyncronous interaction during 12 weeks.

The teachers learned to work in e-learning enviroment by using inquire-based learning (IBL) and problem-based learning (PBL) models. The study of climate change as the central theme was performed through a complete analysis of several international cases. Finally, each teacher created a syllabus to teach climate change in high school.

The project results were very successful demonstrated through individual and team learning. Furthermore, it was possible to measure an increasing interaction
\end{abstract}

* $\quad$ Ph.D. Professor, Associate Director - Grosvenor Center for Geographic Education, Department of Geography, Texas State University, United States. E-mail: o.muniz@txstate.edu 
and virtual collaboration among participants. Cooperation was also an indirect benefit given evidences among participants to maintain future academic and social relationships.

Key words: Geography education, network, online education, climate change.

\section{Resumen}

La educación online se identifica como un nivel e-learning más avanzado que la educación a distancia. La primera representa un proceso de red dinámica generada por los miembros que integran una comunidad de práctica. Este artículo describe el desarrollo de una experiencia de educación online a través de una red dinámica de nodos representados por profesores activos de enseñanza media en geografía y ciencias sociales. El proyecto identificado como "RedOnlineIPGH" tuvo una dimensión Panamericana por su extensión geográfica.

Un portal digital creado en la Universidad Estatal de Texas, identificado como Nodo-1, coordinó una red de 16 nodos adicionales localizados en varios países de América Central y América del Sur. El Nodo-1 en América del Norte mantuvo una conexión permanente con todos los nodos para permitir una interacción sincrónica y asincrónica durante 12 semanas.

Los profesores aprendieron a trabajar en ambiente e-learning utilizando los modelos de aprendizaje basado en indagación $(A B I)$ y aprendizaje basado en problemas (ABP). El estudio del cambio climático como tema central fue desarrollado a través de un análisis acabado de varios casos internacionales. Finalmente, cada profesor creó un programa de curso para enseñar el cambio climático en la enseñanza media.

Los resultados del proyecto demostraron un aprendizaje individual y de equipo muy exitoso. Adicionalmente fue posible medir una creciente interacción y colaboración virtual entre los participantes.

La cooperación fue también un beneficio indirecto dadas las evidencias entre los participantes por mantener futuros lazos académicos y sociales.

Palabras claves: educación geográfica, red, educación online, cambio climático.

\section{Resumo}

A educação on-line representa um nível de e-learning mais avançado do que a educação a distância. 0 primeiro representa um processo de rede gerado por membros que integram uma comunidade de prática. Este artigo descreve o desenvolvimento de uma experiência de educação on-line através de uma rede dinâmica de nós representados por professores de geografia e de ciências sociais do ensino médio. O projeto identificado como "RedOnline-IPGH" teve uma dimensão Pan-americana por sua extensão geográfica. 
Um portal digital criado na Universidade Estadual do Texas, identificado como Node-1, coordenou uma rede de 16 nós adicionais localizados em vários países da América Central e América do Sul. Node-1 na América do Norte manteve uma conexão permanente com todos os nós para permitir a interação síncrona e assíncrona durante 12 semanas.

Os professores aprenderam a trabalhar no ambiente de e-learning usando o aprendizagem baseado em inquérito $(A B I)$ e modelos de aprendizagem baseado em problemas (ABP). $O$ estudo das mudanças climáticas como tema central foi realizado através de uma análise completa de vários casos internacionais. Finalmente, cada professor criou um programa para ensinar mudanças climáticas no ensino médio.

Os resultados do projeto demonstraram que o aprendizagem individual e em equipe teve muito sucesso. Além disso, foi possível medir uma interação crescente e uma colaboração virtual entre os participantes. A cooperação também foi um benefício indireto, dado evidências entre os participantes para manter futuras relações acadêmicas e sociais.

Palavras-chave: educação geográfica, rede, educação on-line, mudanças climáticas.

\section{Introduction}

The Pan American Institute of Geography and History (PAIGH) has encouraged education and scientific development since its creation as an institutional member of the Organization of American States (OAS). The 2010-2020 PAIGH Agenda represents its international responsibility by indicating, among other initiatives, the need for studying climate change in the Region. Furthermore, the Agenda supports the development of professional networks to promote regional integration (PAIGH, 2009). In response to this Agenda, representatives of three countries; Argentina, Honduras and the United States, proposed a training project entitled Red Online of Geographic Learning, identified with the acronym: RedOnline-IPGH. The project was approved and funded by PAIGH in 2015. RedOnline-IPGH followed an initial experience approved by PAIGH in 2013 focused on a distance learning workshop. It was developed in a virtual classroom platform for in-service teachers who learned didactic tools in an Information and Communication Technology (ICT) environment (Cacace, 2014).

This article focuses on the development and results of RedOnline-IPGH. The main objective of this project was to prepare and give special training to selected in-service active teachers working in different countries in Latin America. The training program focused on the acquisition and transformation of geographic knowledge on climate change. However, it was part of a more extensive projection 
to spread geography education professional networks through online operations. Hence we intend to understand advantages as well disadvantages of networks in their action to generate networking activities. In this particular experience the researchers responsible for this project pay close attention to the evolution of interaction, cooperation and collaboration among professionals who are engaged in geography teaching in secondary schools. Consequently, the activities for the RedOnline-IPGH project were arranged in two main parts: the structural plan (i.e., activities 1, 2 and 3) and the online program (i.e., activities 5, 6 and 7). Activities 4 and 8 were the initial and final phases of operations, respectively. Table 1 shows the timetable for 2015-2016.

Table 1

Timetable-RedOnline-IPGHProject

\begin{tabular}{|c|c|c|c|c|c|c|c|c|c|c|c|c|}
\hline & 201 & & & & & & & & & & & 016 \\
\hline ACTIVITY & 2 & 3 & 4 & 5 & 6 & 7 & 8 & 9 & 10 & 11 & 12 & 1 \\
\hline 1. Preparation of LMS and Portal & $\rightarrow$ & & & & & & & & & & & \\
\hline 2. Network Structure & & $\Rightarrow$ & $\rightarrow$ & & & & & & & & & \\
\hline 3. Learning Modules & & $\Rightarrow$ & $\rightarrow$ & $\Rightarrow$ & & & & & & & & \\
\hline 4. Data Base. Final registration & & & & $\rightarrow$ & $\Rightarrow$ & & & & & & & \\
\hline 5. Phase A. Interaction Process & & & & & & $\Rightarrow$ & $\rightarrow$ & & & & & \\
\hline 6. Phase B. Cooperation Process & & & & & & & $\Rightarrow$ & $\Rightarrow$ & & & & \\
\hline 7. Phase C. Collaboration Process & & & & & & & & $\Rightarrow$ & $\Rightarrow$ & & & \\
\hline 8. Phase D. Closing and Evaluation & & & & & & & & & & $\Rightarrow$ & $\Rightarrow$ & $\Rightarrow$ \\
\hline $\begin{array}{l}\text { 1. LMS and Portal preparation. Adaptatio } \\
\text { 2. Network reliability analysis. Identificat } \\
\text { 3. Learning module integration. Preparati } \\
\text { 4. Data base selection. Final selection of } \\
\text { 5. Interaction process. Theory and practic } \\
\text { 6. Cooperation process. Regional and loc } \\
\text { 7. Collaboration process. Syllabus prepar } \\
\text { 8. Closing and evaluation. Questionnaire }\end{array}$ & $\begin{array}{l}\text { tate L } \\
\text { le no } \\
\text { ction } \\
\text { acher } \\
\text { chan } \\
\text { Proble } \\
\text { esenta } \\
\text { and in }\end{array}$ & $\begin{array}{l}\text { rersity } \\
\text { and } 1 \\
\text { A inte } \\
\text { odes) } \\
\text { Worl } \\
\text { on cl } \\
\text { As. St } \\
\text { al ev }\end{array}$ & $\begin{array}{l}\text { atfor } \\
\text { ion } \mathrm{Co} \\
\text { d reg } \\
\text { ase sc } \\
\text { te ch } \\
\text { gies } \\
\text { ation }\end{array}$ & $\begin{array}{l}\text { LMS } \\
\text { ectivit } \\
\text { veen } \\
\text { ation } \\
\text { arios. } \\
\text { ge. P } \\
\text { teach } \\
\text { d asse }\end{array}$ & $\begin{array}{l}\text { vels } \\
\text { S-CC } \\
\text { activ } \\
\text { met } \\
\text { neth } \\
\text { clim } \\
\text { nent. }\end{array}$ & $\begin{array}{l}\text { web } \\
\text { ork } \\
\text { pplic } \\
\text { chang } \\
\text { chnica }\end{array}$ & $\begin{array}{l}\text { and } \\
\text { ion } \\
\text { n }\end{array}$ & $\begin{array}{l}\rightarrow \mathrm{R} \\
\rightarrow \mathrm{I} \\
\rightarrow \mathrm{R}\end{array}$ & $\begin{array}{l}\text { earch de } \\
\text { al and } \\
\text { ive phas }\end{array}$ & $\begin{array}{l}\text { e\#1) } \\
\text { ital } \\
\text { and } 1 \\
\text { phase } \\
\text { of oper }\end{array}$ & $\begin{array}{l}\text { ing } \mathrm{m} \\
\text { opera }\end{array}$ & \\
\hline
\end{tabular}

The online program designed to develop Phases A, B and C (active phases of operation) was performed to guide in-service teachers in the learning process of climate change. The inmediate purpose was to allow participants the acquisition of basic knowledge of global weather transformation. The exposition to learning modules based on selected case studies took each participant into the inquiry stage to investigate some particular physical processes. A more gradual purpose leaned toward discovering the creation and evolution of interaction and cooperation among participants; two esencial processes of networking. An advanced stage took place when participants, either through individual work or as part of teamworks, were exposed to possible climate change evidences presented as local and/or regional problems. As a final stage of the learning process each participant initiated a personal experience to produce a plan for teaching climate change in their own schools. Table 2 shows the sequence of activities and tasks during the online experience that has been described above. 
Table 2

The RedOnline 12-weeks program

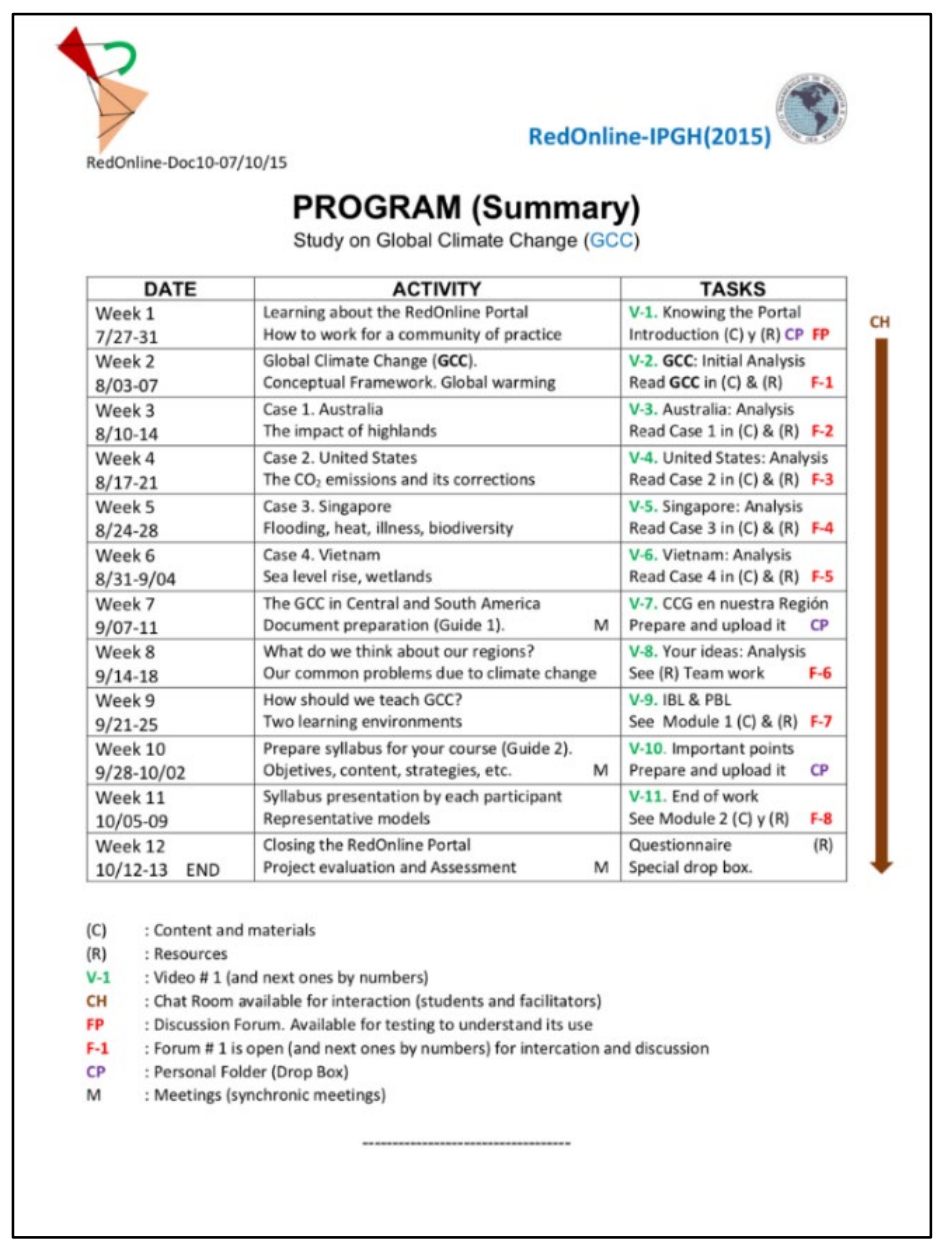

In the process of examining the networking activity along with the online geography teaching, collaboration is the ultimate source of assistance. It tends to be chosen among participants who look for different alternatives to assemble components oriented to explain the dynamic processes involved in climate change. Like in the cases of interaction and cooperation, collaboration requires special procedures to identify the networking activity. Only by selecting these procedures is possible to measure the level of dymanic that the network of inservice teachers were capable to built. Ultimately, there is an important task of building collaboration through a community of practice (CP). This CP is represented by professionals dedicated to secondary education. They are conditioned by the capability of bringing online geography teaching into global learning for the younger generations. 


\section{Teaching Online Geography for Local and Global Learning}

The international responsibility that PAIGH, as a member of OAS, has to study climate change among other physical transformation of the Earth, focuses geography on the direction of an important obligation. It is a duty and a moral imperative to find the best strategies that will allow their citizens of the Americas to learn about geographic awareness as well as fundamental knowledge and skills. Yet the evidence of a dangerous shortfall of millenials with global competence, place the educational system of so many countries in Latin America on notice. It is education and particularly geography education that requires to comply with a system of values and principles of conduct to guide new generations for global understading. Therefore, the question is to what extent both teachers and students can develop global understanding from geographic knowledge and skills they use in a variety of school systems in the Americas. This question should be responded with another question that precedes: What would be the best strategy to communicate and exercise knowledge and skills so to reach a vast majority of teachers and students? An answer to the best strategy that reaches small and large population of teachers and students is full online education. This type of education can be shared not only by small and distant groups of teachers and students in rural schools, but also by teachers and students in large urban sites and metropolitan areas. This strategy was recognized as e-learning system in geography education.

Online education is a more advanced e-learning level than distance education. The former represents a networking process generated by participants who integrate a CP. The development of online learning in geography education presents both challenges and opportunities for teachers in any region of the world. One important challenge is related to the "digital divide"; occurrence that is still a negative factor in the process of global integration (James, 2008). Despite of the fact that the new world of electronic geography presented by Brunn (2003) showed important key features such as global networking, electronic scholarly communities and the rise of virtual libraries in the Americas at the beginning of the $20^{\text {th }}$ century, several Latin American countries are still affected by lack of adequate communication infrastructure and reliable access to digital information.

Within the context of reliable access and adequate communication infrastructure there are also challenges which are immediately present when participants of an online learning activity are seeking new knowledge. Knowledge reproduction and knowledge distribution are in fact the core and final objectives of any CP, as Lave and Wenger (1991) identify its transformation. Situated learning emphasizes the importance of relational attribute that participants of a community have when they engage in interaction with one another. At the level of full online environment, relational qualities represent important conditions for knowledge transformation. This is particularly special when a CP works through cybernetworks and extensive channels for website 
enable community-based input, and content sharing that promote interaction, cooperation and collaboration (Muñiz-Solari and Jiang, 2019). Furthermore, the value of any network where members of a CP are interacting depends upon each participant as independent nodes to act and evaluate the relevance of information flows for themselves and for the total network (Wenger et al., 2011).

The knowledge reproduction and distribution through online interaction entails the process of interactivity among participants. Even when Albrecht and Tillman (2004) indicate that interactivity first involves an individual construction of knowledge followed by a socially embedded knowledge construction, MuñizSolari and Coats (2009) point out that the process is more complex since interaction always starts with two people as a simple form of relationship. The following steps are possible cooperation and collaboration; two distinctive forms of advanced interaction. The first characterizes a group while the second is a teamwork. The latter normally implies trust and confidence among participants, as a result of continuous work and increasing experience. The former is still in the process of reaching a socially embedded knowledge construction because it requires more permanent interaction that can better attained by discussion forums than just chat-room activity (Figure 1).

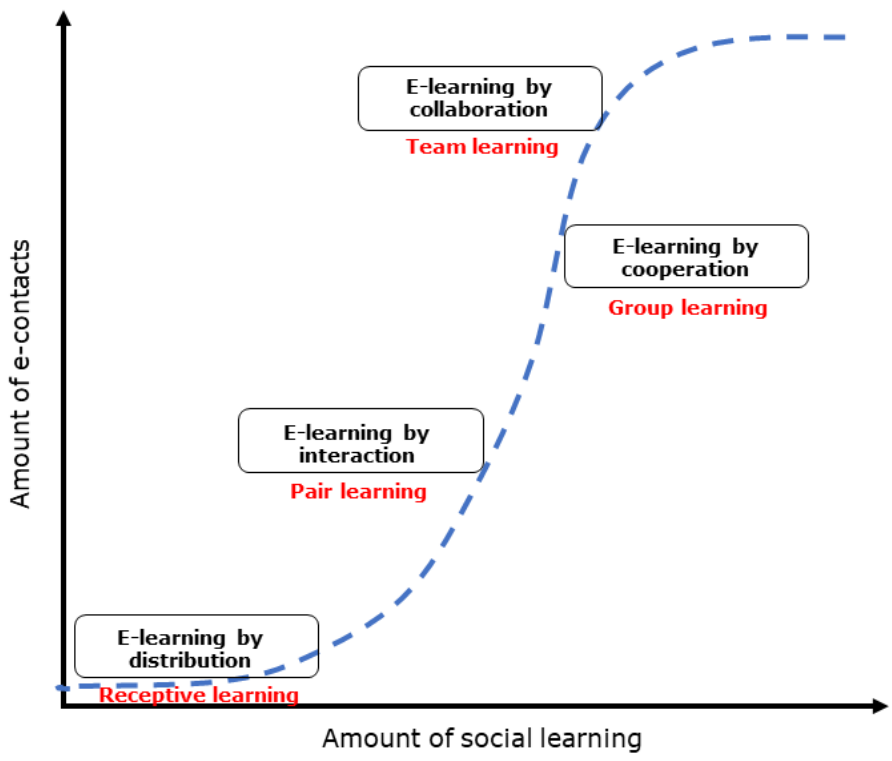

Figure 1. Knowledge construction by increasing social learning. Source: Adapted from Albretcht and Tillmann, 2005; Muñiz-Solari and Coats, 2009.

Certainly, geographic knowledge directly attached to global issues such as climate change are not well taught in the schools in most of the Latin American 
countries. Factors affecting this limitation are related to a lack of in-depth attitudes of acknowledgement and evaluation of the limits of planet Earth regarding human life (Araya Palacios et al., 2018), teaching strategies that are distractors rather than efficient procedures (Schiavone, 2012), and using some tools such as maps and their skills that are inadequate (Perea and Mayor, 2014). The exercise of geographic knowledge and the necessary abilities to use online tools such as chat rooms and discussion forums requires special teaching and learning methods that are adequate to online operations.

A learning experience through full online interaction is conducive to opportunities for faster and deeper learning processes than face-to-face interaction. The exposition to a wide variety of data and information speeds up knowledge production and knowledge transformation. However, this type of acquisition of knowledge almost always requires at least the combination of two learning methods. First, Inquiry-based Learning (IBL), explained as the exploration in which each participant is engaged in a thorough examination and a systematic investigaction of some matter in question to seek detailed information. In examining the efficacy of inquiry-based approaches to education, Scott et al., (2018) emphatically highlight the specific instructional supports needed to reach critical thinking and flexible problem solving abilities. We agree with the authors that pedagogical practices and instructional supports are fundamental conditions to reach a successful learning experience. The same can be said with pedagogical practices developed with online instructional support.

Second, Problem-based Learning (PBL) is recognized as the study of a "real world" open-ended problem. It provides participants with the opportunity to work independently as well as in groups and teams. Furthermore, it creates environments for learning together as Pulgarin and Scoones (2017) point out their social approach (instructor-students; student-student) to analyze problems in the Colombian schools.

PBL has a social constructivist framework because a person's knowledge is interiorized as a result of interacting with the social environment (Fetsco and McClure, 2005). However, as opposed to a classroom environment this interaction takes place in a very special social environment characterized by digital connections. Within this teaching and learning web participants are frequently exposed to asynchronous contacts, reducing the possibility of perfect face-to-face replication of a classroom. Synchronous contacts can reach a quasiperfect replication of a classroom environment yet they are less common due to technology restrictions. Nevertheless, asynchronous communication conducted through online discussion forums shows evidence of frequent participation in problem-solving engagement. Chao et al., (2018) recently demonstrated the importance of proactive online discussion forum in which participants seek assistance from experts to resolve problems. 


\section{Research Design and Learning Methods}

The research was composed of two main designs: the structural arrangement and the networking process. The structural plan was based on three components: the network organized by specific nodes and special links, the platform or LMS and portal, and the learning modules. Each component has certain conditions that need to be achieved based on two learning methods in order to be an effective geography education online program.

\section{The Structural Arrangement}

\section{The Network}

The network integrates 16 nodes located in specific countries. One node was assigned as the LMS and identified as "Node-1". Each selected node is represented by a high school teacher who is interested in and capable of developing an online experience. Thus, the network was functional thanks to a basic knowledge on distance education and a reliable connectivity to Internet demonstrated by each participant's location. These conditions were tested through an initial contact with each participant to verify stable link connectivities (e.g., bidirectional and multidirectional linkages) throughout the online experience. The final list of countries was determined by the location of in-service teachers with at least one year of continuous school teaching activity who applied and were accepted to be part of this project advertised through the PAIGH special information (Figure 2).

\footnotetext{
- Nodes (Central America)

- Nodes (South America)

Node-1 (LMS) United States
}

\begin{tabular}{|c|l|}
\hline NODE & \multicolumn{1}{|c|}{ COUNTRY } \\
\hline A1 & Argentina \\
\hline B1 & Belize \\
\hline C1 & Brazil \\
\hline D1 & Chile \\
\hline E1 & Colombia 1 \\
\hline E2 & Colombia 2 \\
\hline F1 & Costa Rica \\
\hline G1 & Ecuador 1 \\
\hline G2 & Ecuador 2 \\
\hline G3 & Ecuador 3 \\
\hline G4 & Ecuador 4 \\
\hline H1 & Honduras 1 \\
\hline H2 & Honduras 2 \\
\hline H3 & Honduras 3 \\
\hline H4 & Honduras 2 \\
\hline J1 & Uruguay \\
\hline & \\
\hline
\end{tabular}

Figure 2. The network structure. Central America and South America. 


\section{The Platform and Portal}

The platform designed for this online international experience was the official LMS available at Texas State University and identified as TRACS. It was chosen to expedite continuous and stable distribution of information in more than one language as well as facilitating permanent interaction, cooperation and collaboration. The LMS was adapted with a special Portal identified with the acronym: RedOnline. For the purpose of the network organization Portal RedOnline was Node-1. This Portal was designed to utilize several functions to be managed either in Spanish, Portuguese or English; the three languages accepted for this international online experience (Figure 3).

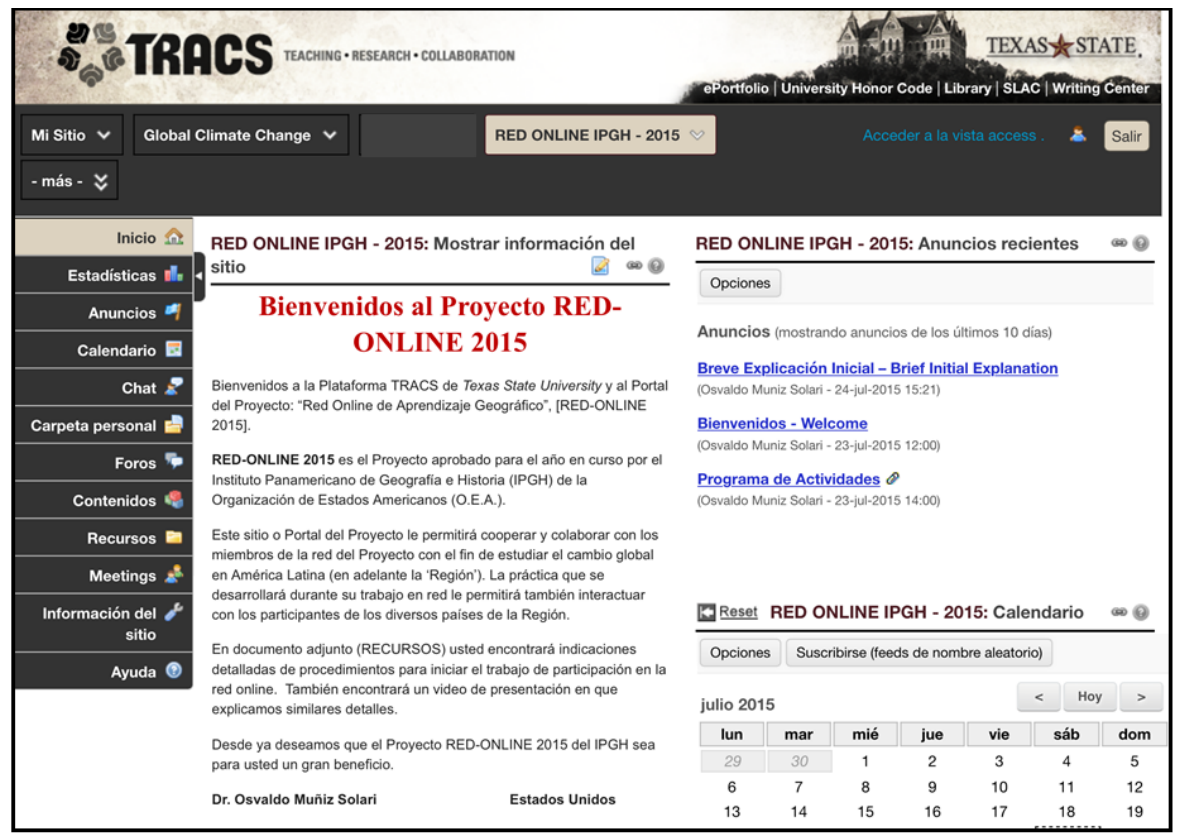

Figure 3. LMS (TRACS) and Portal RedOnlineIPGH-2015.

\section{The Learning Modules}

The learning modules were structured as four case studies representing four countries; each of which showed several environmental issues related to climate change. The American Association of Geographers (AAG) allowed the use of the learning modules produced by the Center for Global Geography Education (CGGE); an international project funded by the National Foundation and supported by the AAG. 
The case of Australia focused on the impact on the highlands, while the case of the United States concentrates on the $\mathrm{CO}_{2}$ emissions and its corrections. The Singaporean case took the participants to various issues such as inundation, heat, sickness, and biodiversity. The final learning module analyzed Vietnam with its sea-level rise and wetlands. Overall, the structure of the learning modules paved the way to initiate and develop an interaction among participants.

\section{The Networking Process}

The model selected to organize the tools and functionality for international networking has a dual configuration that dynamizes the use of resources and web contents by either digital or non-digital sources. Both types of sources were utilized to enhance the use of several learning modules designed to analyze issues on climate change as presented through case studies from different countries. Chat room activity and forum discussion were the two channels to perform interaction, cooperation and collaboration among in-service teachers (Figure 4).

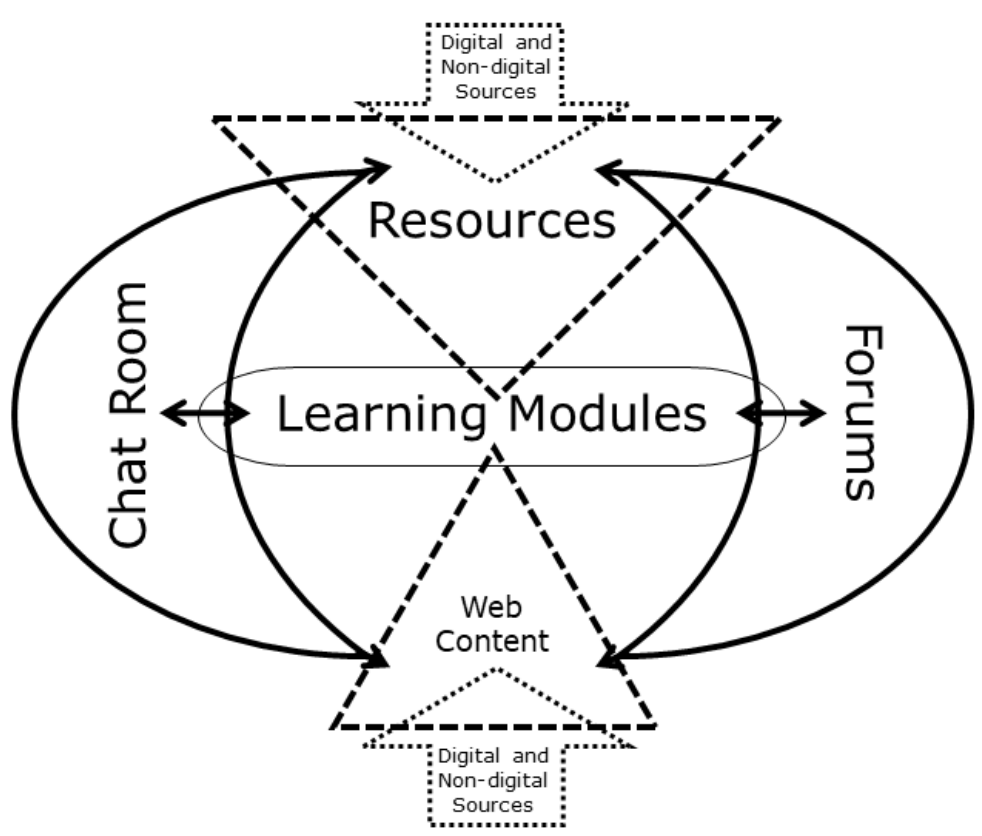

Figure 4. The model for online education with tools and functionality for international networking. Source: Muñiz Solari, 2017.

The networking process was always initiated with live presentations by the facilitators followed by interaction, cooperation and collaboration performed by 
each participant and several teams. Eleven live presentations guided the process of initial and basic information related to each topic on climate change. Each presentation was technically designed with TechSmith and Camtasia Relay for screen recording and closed captioning. Figure 5 shows a typical online live presentation developed during the first period of the RedOnline-IPGH Project

The online activities among participants were developed in 12 weeks. The inservice teachers kept continuous interactions to maintain an active network during three months. In other words, they had permanent participation via the chat room since week one, besides forum discussions each week during eight consecutive weeks. Thus, the networking process that started with dynamic interactions and cooperations among participants was increasing throughout the online activities to finally reach collaboration. Furthermore, the learning modules created the conditions to discover local and regional issues by the in-service teachers as potential new case studies to be incorporated in their curricula in the schools.

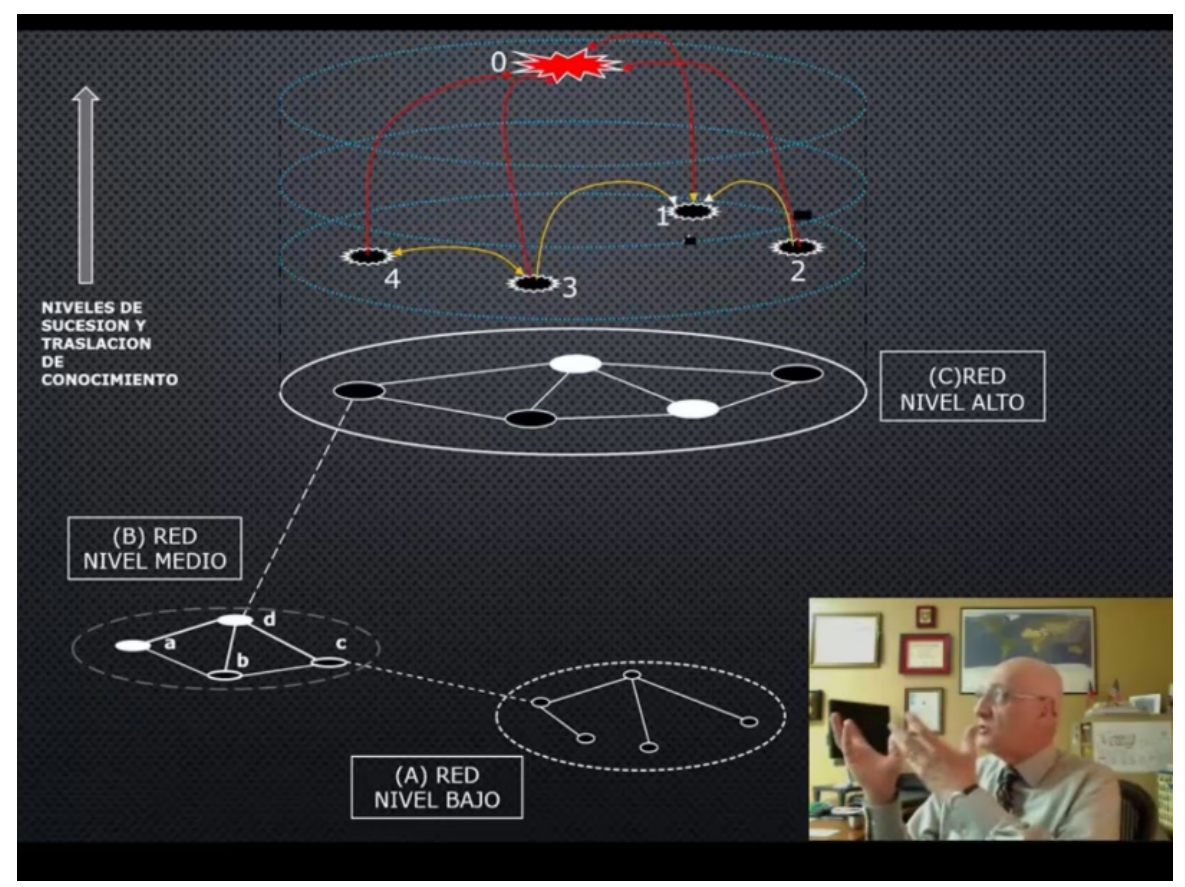

Figure 5. Explaining the network via online live presentation.

\section{The Learning Methods}

The analysis of local problems studied by each participant and the subsequent activities developed by the whole group was perfomed with two learning 
methods. In order to analyze particular issues derived from the case studies, each participant collected information through individual inquiry. For this purpose, IBL was the assigned method or operation. From individual work to group formation, each participant approached to cooperation and collaboration progressively. The more advanced work involved the analysis of local and regional problems to be discussed and presented with solutions by applying PBL method. Both learning methods allowed interaction among participants while the advance stages of cooperation and collaboration were performed exclusively with PBL. Part of this final stage was also complemented with the proposition to use special tools such as ArcGIS Online and Story Maps.

\section{Results and Discussion}

The interesting experience with in-service teachers who participated in a distance-education workshop in 2013 demonstrated very positive results. Notwithstanding the unequal working conditions of all the participants when the e-learning experience took place, the in-service teachers' disposition to participate and work was exceptional (Cacace, 2014). A continuation of this first e-learning experience with in-service teachers in Latin America, RedOnline-IPGH project carried out another version that focused on the dynamic processes of an online education program. This new Pan American training program also worked with in-service teachers from various countries. Nevertheless, it went beyond the scope of a workshop that facilitates in-service teachers' learning with didactic tools in an ICT environment. Consequently, the training program was part of a more extensive projection to spread professional networks of geography educators through online operations and understand advantages as well disadvantages of networks in their action to generate increasing networking activities in the future.

\section{Interaction and Cooperation. The Chat-Room Environment}

The starting point for these two important conditions related to socially embedded knowledge construction is the process of building stable linkages between a pair of nodes, among several nodes, and between nodes and the LMS (Node-1). With the exception of Node-1, each node is represented by an in-service teacher located in his or her place of work (e.g., school, office, home). Thus, the linkages are transformed into flow of ideas or knowledge flow network through interaction.

The training activities were developed during 12 weeks within which the most representative operations were IBL applied to the Learning Modules on case studies and PBL applied to local and regional issues related to climate change. In order to measure the interaction process four weeks were selected as follows: Week 3 (IBL for Learning Module 1), Week 5 (IBL for Learning Module 3), Week 7 
(PBL with ArcGIS geospatial tools), and Week 10 (PBL for final report). Table 3 shows the most representative chat-room interactions.

Table 3

Representative chat-room interactions amog participants

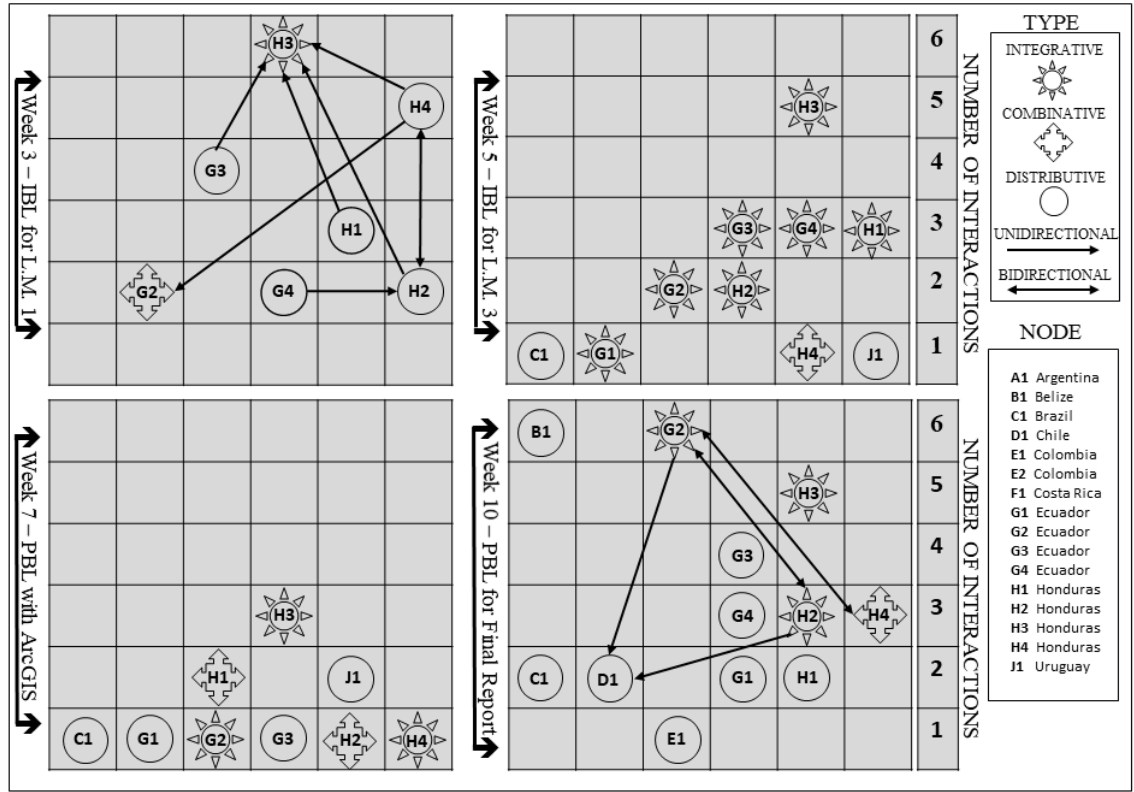

The level of interactions among participants (i.e., node identified by country) performed in the chat rooms was tested during the selected weeks by determining the number, types and direction of interactions that each node put into practice. The number of interactions a participant performed has a range from 1 to 6 . One interaction is defined as one contact a node underwent with either another node or all the nodes. The type of interaction could be integrative (i.e., serving or intending to unify several ideas), combinative (i.e., serving or intending to combine two ideas), and distributive (i.e., serving or intending to disseminate one or several ideas). The interaction can have an additional characteristic related to flow direction. Unidirectional flow, when one participant shares ideas with a specific participant who is identified by his/her name. Bidirectional flow, when ideas are sharing between two or more participants who are identified by their names. Otherwise, interaction is understood as performed by one participant with all participants.

Table 3 summarized the most representative interactions among participants identified by country nodes. Week 3 (IBL for Learning Module 1 ) showed a reduced number of participants performing interaction; however, three participants presented high interactions (between 4 and 6). This was the beginning of 
activities with the first Learning Module. A possible interpretation is that some participants were still trying to learn how this environment worked, while others tended to initiate the interaction quite well. In any case, the most common type of interaction is distributive. Yet the presence of a leader was evident who presented an integrative form of interaction while capturing the flows of ideas through unidirectional flows. Week 5 (IBL for Learning Module 3) results demonstrate a quick reaction from several participants when they engaged in integrative mode of operation. The process of unifying ideas among participants is a clear evidence of group work rather than individual work as it was the case of chat-room activities during Week 3 . The manifestation of a transitional process toward cooperative work might have started during the completion of Week 4; a stage that was not selected for Table 3, but it was already included in the overall analysis and interpretation. It is important to notice that the interactions among participants did not have specific directions, a clear corroboration of a transition from individual work to group activity by cooperative tendency. Furthermore, the dissemination of ideas (distributive type); the lowest type of flows, was performed by only two participants with minimum interaction.

It is important to remember that Week 3 and Week 5 are part of IBL procedures, while Week 7 and Week 10 concentrate participants mostly in PBL exercises. The results of Week 7 (PBL with ArcGIS) presented a rather different scenario compared to the preceding weeks. At this point, the inclusion of new geospatial tools such as ArcGIS online and Story Maps, created complicaton in the interaction process. The tools were offered to develop the necessary skills by each participant and improve the analysis of local and regional problems on climate change. However, it was noticeable that the in-service teachers required more time to complete a special training for this purpose. Therefore, the interaction process showed perceptible signs of reduction in terms of both the number and type of interactions. A plausible explanation is the lower level of preparation related to geospatial technologies.

When the in-service teachers entered Week 10 (PBL for Final Report) the activity required special interaction and even cooperation to facilitate the completion of individual reports on local and country issues related to climate change. Intentions to diseminate one or several ideas about ways to prepare the report and discuss specific issues on climate change were evident. Eight participants out of twelve were inclined to perform distributive actions that represented a good example of cooperation. Moreover, the distribuitive mode of operation was completed with two, three and even four interactions, emphasizing the intention for advanced cooperation. Serving or intending to unify several ideas on the report preparation were fulfilled by three participants. Two participants carried out this integrative process with unidirectional and bidirectional flows.

The overall result corroborates the increasing interaction and cooperation. This gradual transformation occurs when a group of participants are exposed to gradual implementation of activities, such as the Learning Modules with 
international case studies on climate change. An example of interaction during Week 4 (Learning Module: United States. The $\mathrm{CO}_{2}$ problem) shows evidence of integrative mode of operation with bidirectional flow:

Participant 7 (19-ago-2015 23:10 CDT) Estimado Yan, en relación a los dos postulados sugeridos en la intervención con Aldo, en cómo hacer que el tema se encadene hasta las familias y comunidad creo que se debe considerar las estructuras comunitarias que están involucradas en nuestras instituciones educativas para ofertar a través de ellos espacios reflexivos de compartimiento de la realidad del CCG y desde estas instancias promover presión a los gobiernos locales para llegar acuerdos que sean sostenibles.

An example of interaction during Week 6 (Learning Module: Vietnam. Sea level rise and wetlands) shows evidence of distributive mode of operation without directional flow:

Participant 4 (03-sep-2015 21:49 CDT) Hola de nuevo!! Son realmente preocupantes las proyecciones que se esperan para Vietnam derivado los fenómenos como ser las marejadas ciclónicas, los tifones y el aumento del nivel del mar, entre otros. Esto traerá consecuencias biofísicas y socioeconómicas que requieren medidas contundentes e inmediatas. De igual forma hay que tomar en cuenta que los estudios de caso hasta ahora analizados son solo algunos ejemplos y que existen más países y regiones que sentirán los efectos del CCG.

An example of interaction during Week 8 (Our common problems due to climate change) shows evidence of combinative mode of operation without directional flow:

Participant 10 (25-sep-2015 11:26 CDT) Hola, a todos, considero que este nuevo video nos permitió observar y analizar dos métodos que en nuestra tarea educativa si la aplicamos, considero que los dos son importantes y que de cierta manera los utilizamos incluso correlacionándolos para un mejor aprendizaje en el aula y con lo que se refiere, a la utilidad del ArcGIS como instrumento de trabajo nos permitirá un aprendizaje más activo y dinámico con nuestros estudiantes. Espero poder seguir compartiendo experiencias me despido sin desearles antes éxitos en su labor educativa.

Cooperation was also an indirect benefit given the evidence that there was intention among participants to maintain future academic and social relationships. An example of interaction during Week 12 (Closing the RedOnlineIPGH):

Participant 8 (19-oct-2015 21:42 CDT) Gracias a este proyecto hemos formado una familia ONLINE IPGH, que podremos seguir manteniendo los contactos, por cierto tenemos las direcciones de todos los participantes de este proyecto. Espero que sigamos comunicándonos puesto que tenemos algo en común "somos maestros". Un abrazo a todos. 


\section{Collaboration. The Discussion Forum}

The first part of the results analyzed the progression of interactions among participants of this online training program. The process of moving gradually towards a more advanced state of interaction took the majority of the participants to experience cooperation. They transitioned from individual work into group activity by sharing ideas through various modes of operation. The dynamic process of interaction is now analyzed to a higher level of problem-solving engagement.

At this point of the analysis is necessary to remember the introductory statement of this article. We have said that similar to interaction and cooperation, collaboration requires special procedures to identify the networking activity. It is possible to measure the level of progress the network of in-service teacher were capable to build by selecting special procedures. These lines of action are intimately related to the way teachers develop their knowledge according to cultural and professional values. Ultimately, a CP of in-service teachers is created and nurtured for the purpose of delivering good teaching and perform individually as successful guiders of new generation of students. In this special CP, their members have to be competent in bringing online geography education into the realm of global learning for the younger generations.

The lines of action that allowed us to measure the results of collaboration are based on geographic knowledge construction through problem-solving engagement (KC-PS) and teamwork efficacy through train of thoughts (TE-TT). Both procedures were analyzed via discussion forums and written reports. The activities were contrasted with cultural differences and way of life that are typically different in various subregions of Latin America in order to prevent data misinterpretations. KC-PS was assigned to two levels of geographic knowledge construction to measure efficacy: Level 1 (PBL applied to regional report) and Level 2 (PBL applied to final syllabus proposition). TE-TT was measured by observing the sequence of thoughts given by each participant who integrated an assigned team.

Results of the KC-PS indicate that Level 1 showed less efficacy than Level 2. First, only 11 out of 16 in-service teachers were able to submit a final report to manage a problem related to climate change in the region were they live. In contrast, the preparation of a syllabus to teach climate change in the schools was completed by 13 participants. Furthermore, 69\% of in-service teachers reached a very high mark due to good selection of problems, adequate contents, specific methods, and complete evaluation system. A good explanation of the difference in efficacy between Level 1 and Level 2 is the knowledge progression that took place during the whole KC-PS process. During Level 1 the knowledge distribution on climate change was still in progress while Level 2 already reached the stage of knowledge reproduction. In addition, there was the Discussion Forum component that played a critical role in the exchange of ideas related to climate change. Evidently, this activity presented an increasing participation as the online training 
was approached to the advanced stage of collaborative work. Therefore, opportunities for better and more diversified information, namely 'knowledge reproduction', reached participants more often during the last stages of the training program.

TE-TT shows results based mostly on activities conducted in the Discussion Forum. We defined 'train of thoughts' or track of thoughts as the sequence of interconnected ideas expressed during a discussion forum that might lead or not to knowledge transformation and knowledge reproduction. Socially embedded knowledge construction typically expands during an advanced stage of collaboration where teams are solid in their interaction process. In consequence, the majority of the in-service teachers who participated and completed the online training were able to integrate separate teamworks composed of three or four members. Each team was organized by different subregions in Latin America in order to prevent misinterpretions due to cultural and social regional differences. The train of thoughts among participants were tested by looking at the thread sequence during collaborative work and the integration of ideas that represents well organized geographic knowledge. First, there was no a complete thread sequence to really verify a continuous evolution of geographic knowledge among members of a team. Second, collaboration was occasionally broken by individual participation that was absent from a train of thoughts constructed by members of the same team. The latter may still indicate weak forms of collaboration that prevent team members of constructing new geographic knowledge. The following insertions represent good examples of collaborative work developed in the Discussion Forum 6, Week 7, on climate change.

Discussion Forum 6, Week 7 - Climate Change in my country How the countries in the Region are affected by Climate Change?

Re: Collaborative work $\rightarrow$ Thread

Participant 12 [sep 14, 2015 1:54 PM] TEAM \# 3

En cuanto a los afectos comunes del CCG en nuestra región están por ejemplos la presencia de los fenómenos extremos, es decir, inundaciones en la regiones costeras Caribeñas y las sequías en las regiones próximas a las costa Pacífica durante los meses secos. Ejemplo de ellos en Honduras serían los departamentos de Atlántida y Choluteca respectivamente. En Costa Rica dichos fenómenos, tal como lo describió [Name], se dan entre las provincias de Guanacaste y Limón.

Las consecuencias inmediatas y futuras se verán en las actividades agrícolas y pecuarias, los empleos asociadas a dichas actividades, la inseguridad alimentaria, la mortalidad infantil, problemas de salud, la salinización de los suelos, etc.

Seguramente hay mucho más que decir. Me gustaría leer lo que escriban ustedes para continuar mi participación en este foro correspondiente a la región de América Central.

Discussion Forum 6, Week 7 - Climate Change in my country How the countries in the Region are affected by Climate Change?

Re: Collaborative work $\rightarrow$ Thread

Participant 2 [sep 16, 2015 1:23 PM]

TEAM \# 2 
Hola, Estuve mirando los buenos trabajos de [Name] y [Name] creo que estos son los puntos comunes relacionados a los efectos de los cambios climáticos. Comparando los efectos de cambio climático en Uruguay, Santiago Chile y Rio de Janeiro Brasil podemos notar que existen algunas coincidencias, o sea, efectos comunes como el incremento de eventos extremos como los vientos fuertes en Uruguay, las olas de calor em Rio de Janeiro y sequías prolongadas e inundaciones en Santiago. El incremento de la temperatura en Uruguay será bueno para el turismo en Uruguay (más calor en las playas), entretanto, el turismo también puede sufrir daños por cuenta de la subida del nivel de mar (la erosión y las inundaciones de las playas), lo que para el Rio de Janeiro sería desastroso, pues sus carteles son las playas y su entorno inmediato. Con las temperaturas más grandes, el consumo de energía sufriría mayor demanda en todos los tres casos.

¿Pueden adicionar a esa pequeña reflexión que produje para desarrollar nuestra discusión?

Discussion Forum 6, Week 7 - Climate Change in my country

How the countries in the Region are affected by Climate Change?

Participant 5 [sep 18, 2015 2:53 PM] TEAM \# 1

Estimados compañeros [Name], [Name], [Name], [Name] y [Name], creo que tenemos mucho en común los colombianos y ecuatorianos, partiendo en primer lugar que somos docentes y vamos hacia la misma dirección para cambiar la mente de nuestros niños, adolescentes y jóvenes, orientándoles hacia el buen vivir, en los retos que tenemos que asumir todos los seres humanos, en ser parte de la solución de los problemas y de afrontar el cambio climático antropogénico que emiten gases de efecto invernadero.

La crisis climática es sólo una advertencia de la crisis multidimensional y el colapso de un modelo insostenible de desarrollo basado en el consumo, la acumulación egoísta, la falta de distribución e inequidad y el irrespeto a la naturaleza con la tala y quema de bosques e incendios provocados por pirómanos.

It is important to clarify that interaction, cooperation and collaboration were performed either in Spanish or English. The latter used by one participant from Belize. Portuguese language was only used by the Brazilian participant for the written documents such as the report for regional problems and the syllabus propositions to be implemented in the schools where the in-service teachers work.

\section{The Networking Process}

The final analysis and results are related to the possible construction of a networking process. We have stated that a more extensive projection of the inservice teachers training is the spread of professional networks through online operations. The overall objective of the RedOnline-IPGH project was to understand advantages as well disadvantages of geography education professional networks in their action to generate networking activities.

Let us begin this analysis by giving the appropriate importance to language. Language should be considered as a factor that may promote or inhibit the 
dynamic of a network in this particular experience. The possibility that there may be clusters of participants by the type of language participants use in the interaction process is more evident in regions were several languages and even dialects are spoken. This is not the case of Latin American countries. However, the use of three languages in this international experience was not even. Spanish language dominated the network and this fact might have affected not only more effective participation by some members but also the efficiency and evolution of interactions throughout the whole network.

The analysis of the networking process was accomplished with the interplay of three basic variables: dominance, flow type and collaborative nodes. Dominance is defined as the action of leadership exerted by specific nodes. It was calculated with a range 1 to 5 . The greater the dominance the smaller the number. In other words, the greater the leadership the smaller the friction to reach and lead other nodes. Flow type is defined as the level of flow permanence within the network. It has five characteristics attached to dominance level degradation. The flow could be dominant, permanent, fluctuant, dilatory or absent. Collaboration is defined as the representation of nodes acting as team members of a single or multiple flow type.

Three nodes presented dominance in the network (value $=1$ ) with dominant flows over three collaborative nodes. These nodes were either first (value $=1$ ) or second (value $=2$ ) in dominance with permanent flows. Four nodes presented values $=2$ with permanent flows with other three nodes. Only 3 nodes were assigned values $=3$, experiencing fluctuant flows, some of which are associated to nodes that are high in dominance (value $=1$ ). Three nodes were assigned values $=4$, demostrating dilatory flows, some of which are associated to nodes with value $=1$ or nodes with value $=2$. Finally, four nodes were located the bottom of the scale in dominance. In other words, they are absent in most of the flows and sometimes captured by nodes with the highest dominance (value $=1$ ). As a result of this tracking interpretation the networking process is still in its early stage of development (Figure 6).

Nodes collaboration can reduce the time spent with Node 1 (LMS) and homogenize the effort to move good ideas through the network and, eventually, speed up the process of knowledge production and knowledge transformation. At the present time, we can say that it is possible to see interaction, cooperation and collaboration. Yet the networking process requires a more sophisticated interaction, feasible to be created with more dedicated in-service teachers acting as member of a highly active $\mathrm{CP}$.

\section{Conclusions}

The RedOnline-IPGH has demonstrated to be a successful experience for training in-service teachers in online teaching and learning as well as measuring the 
_ Flows LMS-to-Nodes. Central America and South America.

- (asynchronous \& synchronous interactions)

- Flows Node-to-Node. Central America and South America Nodes (mostly asynchronous interactions)

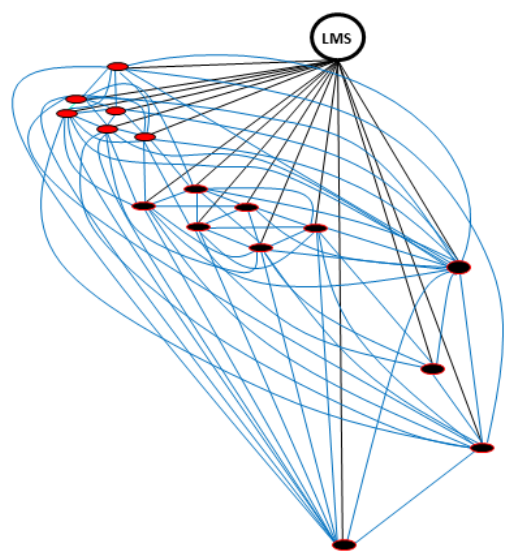

\begin{tabular}{|c|c|c|l|}
\hline NODE & A & B & \multicolumn{1}{|c|}{ C } \\
\hline A1 & 5 & absent & J1 \\
\hline B1 & 4 & dilatory & H2-H3 \\
\hline C1 & 3 & fluctuant & D1-E1-G2 \\
\hline D1 & 2 & permanent & G3-E2-H2 \\
\hline E1 & 1 & dominant & E2-G2-G1 \\
\hline E2 & 5 & absent & E1 \\
\hline F1 & 5 & absent & B1 \\
\hline G1 & 2 & permanent & G2-G3-D1 \\
\hline G2 & 1 & dominant & G1-G3-E1 \\
\hline G3 & 3 & fluctuant & G1-G4-E1 \\
\hline G4 & 4 & dilatory & G2-G3 \\
\hline H1 & 2 & permanent & H2-H3-F1 \\
\hline H2 & 1 & dominant & G2-H3-H1 \\
\hline H3 & 2 & permanent & H2-H1-B1 \\
\hline H4 & 4 & dilatory & H2-G2 \\
\hline J1 & 5 & absent & A1 \\
\hline
\end{tabular}

A: Dominance, B: Flow Type, C: Collaboration

Figure 6. The networking process. Dominance, low type and collaboration.

evolution of a networking process in the Pan American world. Interaction, cooperation and even collaboration are totally achievable through full online geography education.

Even when the 'digital divide' is still present in our regions and especially in the most remote rural areas, Latin America has walked fast to reduce the gap and make information and communication technologies more accessible. PAIGH as contributed in this direction and we are certain that more experiences will be promoted and supported. Both knowledge of global issues and the need for technological progress are important components of geography education.

The results of this international experience have open major channels to initiate future investigation. The objective is to enhance the training process in geography education of other community of professionals in the Pan American world. The starting point has two possible avenues. First, the improvement of LMS with new tools and inter-operational functions to increase the networking process. The model proposed in Figure 7 expands the use of new tools and additional skills for better combination between geographic knowledge and geospatial technology environments.

The second point of initiation toward a more efficient networking process is the application and use of new tools for synchronous activities. Meetings in real time and Wikis may enhance collaboration and knowledge reproduction as well as knowledge distribution. 
Finally, it may be practical to expand this experience toward other future professionals in geography education. I propose the inclusion of pre-service teachers that are prepared in different universities in Latin America. They should be invited to experience full online geography education and be part of the discussion on global issues.

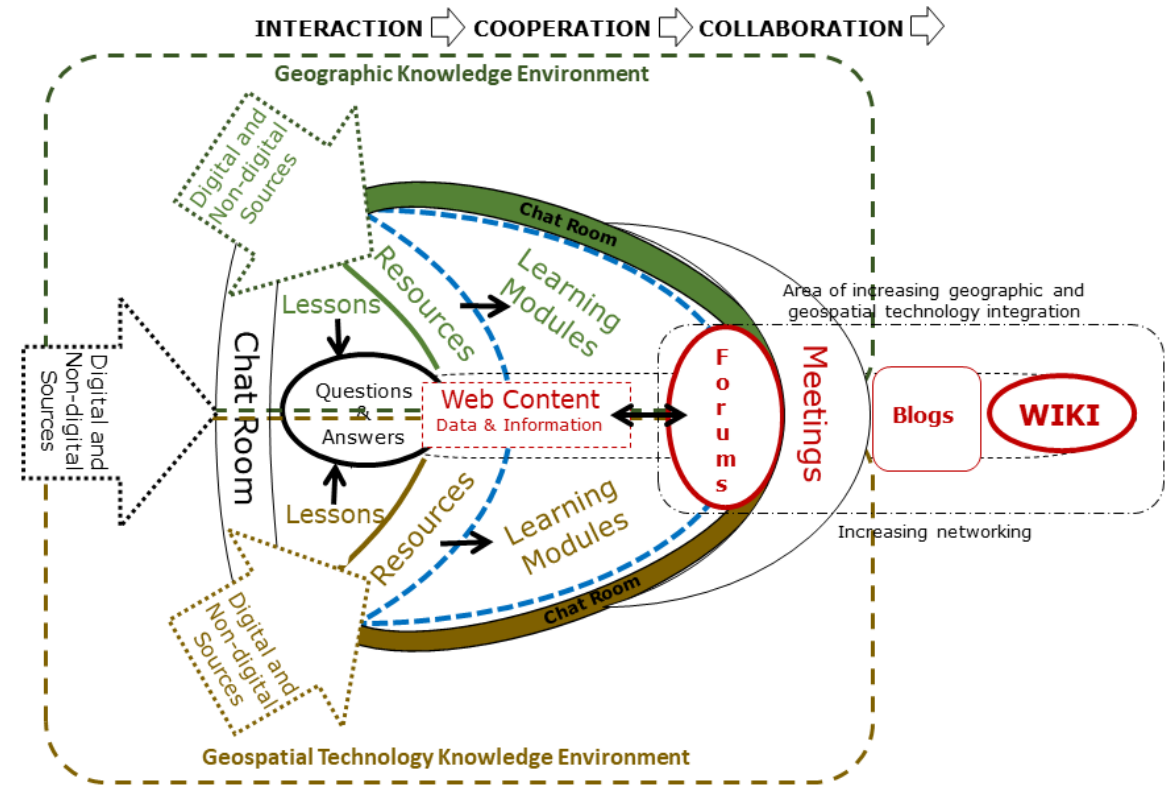

Figure 7. LMS with tools and interoperational functions for networking. Source: Muñiz Solari, 2017.

\section{Acknowledgments}

I thank our professional partners, Lic. Graciela Cacace, Universidad Nacional de Luján, Argentina and Dr. María Cristina Pineda de Carías, Universidad Nacional Autónoma de Honduras for their work and assistance to create this project and give guidance during its development. I also thank Dr. Alejando Cascante Campos for his contribution as facilitator of the training program.

The RedOnline-IPGH project was presented in three international scientific conferences with the following approaches: "A Model for Global Geography Education" at the American Association of Geographers (AAG) in Chicago, April 23, 2015. "International Online Geographical Education with Geospatial Technologies" at the International Geographical Union (IGU) in Beijing, August 24, 2016. "Central American and South American Online Network" at the Conference of Latin Americanist Geographers (CLAG) in San José, Costa Rica, May 22, 2018. 
I am grateful to the numerous participants who made comments and suggestions on several issues and allowed the improvement of the final version of this paper.

\section{References}

Albrecht, A. and Tillmann, V., E-learning and geographical knowledge construction in higher education, Paper presented at the International Geographical Union Congress, Glasgow, Scotland, August, 2004.

Araya Palacios, F., Souton Gonzalez, X. and Claudino, S., "Perspectives on global understanding in Ibero-American countries", en A. Demirci, R. Gonzalez, S. Bednarz (eds.), Geography Education for Global Understanding, Cham, Switzerland, Springer, pp. 131-142, 2018.

Brunn, S.D., "The new world of electronic geography”, Geotrópico, 2003. Retrieved June 21, 2019, from <http://www.geotropico.org/1_1_Brunn.html>.

Cacace, G., "Taller de educación a distancia. Enseñar a aprender geografía utilizando nuevas tecnologías de la comunicación y de la información”, Revista Geográfica, 155(1): 25-45, 2014.

Chao, P-.Y., Robert Lai, K., Liu, C-C. and Lin, H-M. , "Strengthening social networks in online discussion forums to facilitate help seeking for solving problems", Educational Technology \& Society, 21(4): 39-50, 2018.

Fetsco, T. and McClure, J., Educational psychology: An integrated approach to classroom decisions, New York, Pearson Education, 2005.

James, M.J., The digital divide across all citizens of the world: a new concept, Social Indicators Research, Tilburg, The Netherlands, 2008. Retrieved from <https://pure.uvt. nl/ws/files/917495/fulltext.pdf>, August 15, 2019.

Lave, J. and Wenger, E., Situated learning: legitimate peripheral participation, New York, Cambridge University Press, 1991.

Muñiz Solari, O. and Coats, C., "Integrated networks; national and international online experiences", International Review of Research in Open and Distance Learning, 10(1): 1-19, 2009.

Muñiz Solari, O. and Cascante Campos, A., "Multi-efficient strategy to enhance platforms for online geography education", en Abstract of the Annual Meeting of the Southwest American Association of Geographers, Huntsville, Texas, 2017.

Muñiz Solari, O. and Jiang, L., "The Shanghai Model for Global Geography Education”, Part II, Asian Case Studies: Chapter 7, en J.C. de Mora, Kerry J. Kennedy (eds.) Schools and informal learning in a knowledge-based world. Asia-Europe education dialogue, New York, Routledge, 2019, 99-118 pp.

PAIGH, Pan American Institute of Geography and History, Decálogo para la Implementación de la Agenda Panamericana del IPGH 2010-2020, Resolución No. 4, 19 Asamblea General, Quito, Ecuador, octubre 28-30, 2009.

Perea Alvarez, R. and Mayor Salazar, J.C., "La cartografía como instrumento de comunicación en la planificación del espacio geográfico", Entorno, 10: 180-193, 2014.

Pulgarin Silva, R. and Scoones, A.E., La geografía escolar y el estudio de problemas sociales relevantes. Una Apuesta a la Educación Ambiental, en Bianchi Parraguez, R., Arenas Martija, A., Scoones, A.E., Pulgarin Silva, R. Pimienta Betacur, A. (eds.), Un incentivo 
para el conocimiento geográfico y la resolución de problemas espaciales destinado a profesores de enseñanza básica/primaria en países Latinoamericanos, Santiago, Chile, LOM, 2017, 39-54 pp.

Schiavone Canepa, G.G., "El empleo de estrategias innovadoras en la enseñanza de la geografía”, Cuadernos de Geografía, 1: 111-131, 2012.

Wenger, E., Trayner, B. and De Laat., M., Promoting and assessing value creation in communities and networks: a conceptual framework, Ruud de Moor Centrum, Open Universiteit. Report number 18, 2011. 